\title{
Lower Maastrichtian cyclostratigraphy of the Bidart section (Basque country, SW France): A remarkable record of precessional forcing
}

\author{
Dorothée Husson $^{\mathrm{a}, \mathrm{c}}$, Nicolas Thibault ${ }^{\mathrm{b}}$, Bruno Galbrun ${ }^{\mathrm{c}}$, Silvia Gardin ${ }^{\mathrm{d}}$, \\ Fabrice Minoletti ${ }^{c}$, Brad Sageman ${ }^{a}$, Emilia Huret ${ }^{\mathrm{e}}$
}

\footnotetext{
a Department of Earth and Planetary Sciences, Technological Institute, 2145 Sheridan Road, Evanston IL, 60208-3130, USA

b Institute for Geography and Geology, University of Copenhagen, Øster Voldgade 10, DK-1350 Københavns K., Danmark

c Institut des Sciences de la Terre-Paris (UMR 7193), Université Pierre et Marie Curie, 4 place Jussieu, 75252 Paris CEDEX 5, France

d Centre de Recherche sur la Paléobiodiversité et les Paléoenvironnements, UMR 7072, Université Pierre et Marie Curie Paris 06, 4, place Jussieu, 75252 Paris cedex 05, France

e Agence Nationale pour la Gestion des Déchets Radioactifs, 1/7rue Jean Monnet, Parc de la Croix Blanche 92298 Châtenay-Malabry cedex, France
}

\begin{abstract}
Cyclostratigraphic analysis of the Maastrichtian limestone-marl alternations of Bidart (SW France) allows the hypothesis of orbital control on lithological cycles to be evaluated. Magnetic Susceptibility (MS), oxygen and carbon isotope measurements, sampled at a high resolution, are analyzed using various cyclostratigraphic tools. A statistically significant orbital signal is detected, with a remarkable record of the precession corresponding to the limestone-marl couplets. This well expressed orbital forcing allows the building of a relative cyclostratigraphic time scale for the MS and $\delta 13 \mathrm{C}$ records based on the $100 \mathrm{kyr}$ eccentricity cycle. The total duration of the section is estimated at $1.44 \pm 0.22 \mathrm{Myr}$. Correlation based on calcareous nannofossil biostratigraphy and comparison of the scaled Bidart $\delta 13 \mathrm{C}$ record to the astronomically calibrated $\delta 13 \mathrm{C}$ signal of ODP hole $762 \mathrm{C}$ shows that the studied section extends from -71.5 to $-70 \mathrm{Ma}$, covering the upper part of Chron C32n.1n and 2/3 of Chron $\mathrm{C} 31 \mathrm{r}$. Oxygen isotope data suggest a $2^{\circ} \mathrm{C}$ cooling of sea-surface temperatures during the studied interval. When placed on the long-term $\delta 180$ trend of the Bidart section, this interval is here recognized as the onset of the early Maastrichtian cooling event. With its excellent record of the precessional forcing, the Bidart section, along with other sections of the Basque country, is a useful tool for the refinement of the Maastrichtian timescale.
\end{abstract}

\section{Keywords}

Maastrichtian; marl-limestone alternations; cyclostratigraphy; magnetic susceptibility; precession; carbon-isotope stratigraphy

\section{Introduction}

One of the most important foundations for the reconstruction of Earth history is the development of high resolution time scales that are reliable throughout the rock record. Cyclostratigraphic approaches, which allow duration estimations of unprecedented accuracy, have led to significant refinements of the Cenozoic time scale (Pälike and Hilgen, 2008; Westherhold et al., 2009). Unfortunately, the quantification of Milankovitch orbital parameters is not always straightforward in older (Mesozoic) sedimentary series, where the orbital signal tends to be less well-preserved. In particular, precessional variations, possessing a short period ( $20 \mathrm{kyr})$ can be difficult to resolve in sedimentary successions that have experienced significant diagenesis. 
Limestone-marl alternations, which are commonly related to astronomical control by the precession (Dinarès Turell et al., 2003; Boulila et al., 2008; Locklair and Sageman, 2008), should be the most suitable lithology to highlight the evolution of orbital precession during the Mesozoic. However, diagenesis has been shown to play an important role in the creation of some rhythmic carbonate successions, distorting and mimicking primary signals (Böhm et al., 2003; Westphal et al., 2010). In the effort to determine a primary or secondary origin of limestone-marl alternations, confirmation of a statistically significant orbital signal can provide useful information.

The Basque Arc Domain possesses very well exposed hemipelagic Maastrichtian sediments along the coast of the Bay of Biscay. Following the pioneering work of ten Kate and Sprenger (1993), an astronomical timescale has been proposed for the late Maastrichtian of this area by Batenburg et al. (2012) based on the analysis of marl alternations and additional proxies at Zumaïa (Spain). A recent integrated study by Dinarès-Turell et al. (2013) presents new cyclostratigraphic studies and high resolution correlations of the late Maastrichtian of Zumaïa, Sopelana and Hendaia sections (Basque Country). The Bidart section, situated in the French part of the Basque country, shows similar limestone-marl alternations, possesses a solid biostratigraphic framework (Manivit and Premoli-Silva in Clauser, 1994; Galbrun and Gardin, 2004), and has already been investigated for magnetostratigraphic purposes (Manivit in Clauser, 1994). However, the resolution of the previous studies was rather low, and precise dating of geological events recorded in the lower Maastrichtian is still lacking.

The hypothesis of precessional control on limestone-marl couplet formation is thus tested in the lower Maastrichtian of the Bidart section by applying a high resolution cyclostratigraphic analysis on magnetic susceptibility and on bulk carbon and oxygen stable isotopes. Additionally, carbon-isotope stratigraphy is compared and tentatively correlated to the astronomically calibrated $\delta 13 \mathrm{C}$ record of ODP Hole 762C (Thibault et al., 2012a).

\section{Geological setting}

The Bidart section belongs to the Basque-Cantabric basin (southwest France) (Fig. 1), where a thick formation of hemipelagic carbonate-rich facies with some turbidites accumulated from the Albian to the Eocene, encompassing a well-defined Cretaceous-Paleogene boundary (Delacotte, 1982; Rocchia et al., 1987; Galbrun and Gardin, 2004; Gorostidi and Lamolda, 1995; Minoletti et al., 2005; Gallala et al., 2009). According to Elorza and Garcia-Garmilla (1998), weak diagenetic overprint in the Bidart section makes it a very suitable area to study palaeoenvironmental evolution during the Maastrichtian, and thus the record of orbitally driven climatic cycles. Nevertheless, a recent study of $87 \mathrm{Sr} / 86 \mathrm{Sr}$ ratios in inoceramids and carbonate matrix on Bidart section by Gómez-Alday et al. (2008) suggests that the diagenesis effect is different on these two carbonate components, and that inoceramids are too altered for $87 \mathrm{Sr} / 86 \mathrm{Sr}$ chemostratigraphy. During the Maastrichtian, an upper bathyal environment dominated the study area, which was situated near a submarine fan (Seyve, 1984) within an active tectonic setting linked to the Pyrenees orogen (Puigdefàbregas and Souquet, 1986). The section studied here is situated $\sim 1 \mathrm{~km}$ south of the CretaceousPaleogene boundary section. It is tilted at $40-45^{\circ} \mathrm{N}-\mathrm{NW}$ and covers $\sim 30 \mathrm{~m}$ of well defined lower Maastrichtian limestone-marl alternations (Fig. 2). Disturbance due to faulting prevented extension of a continuous sampling toward the north, and the section gives way in the South to fractured reddish marls (Clauser, 1994). 


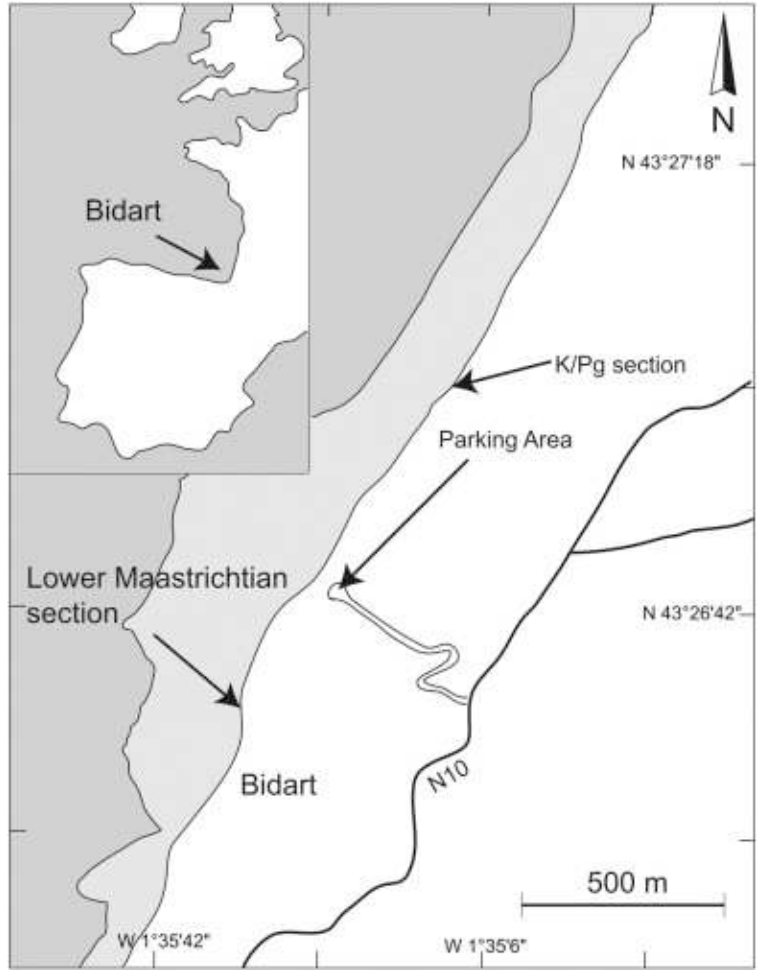

Fig. 1.

Location of Bidart section (modified from Minoletti et al., 2005). This section outcrops in southwest France where a thick formation of carbonate-rich facies interbedded with some turbidites spans an interval from the Albian to the Eocene.

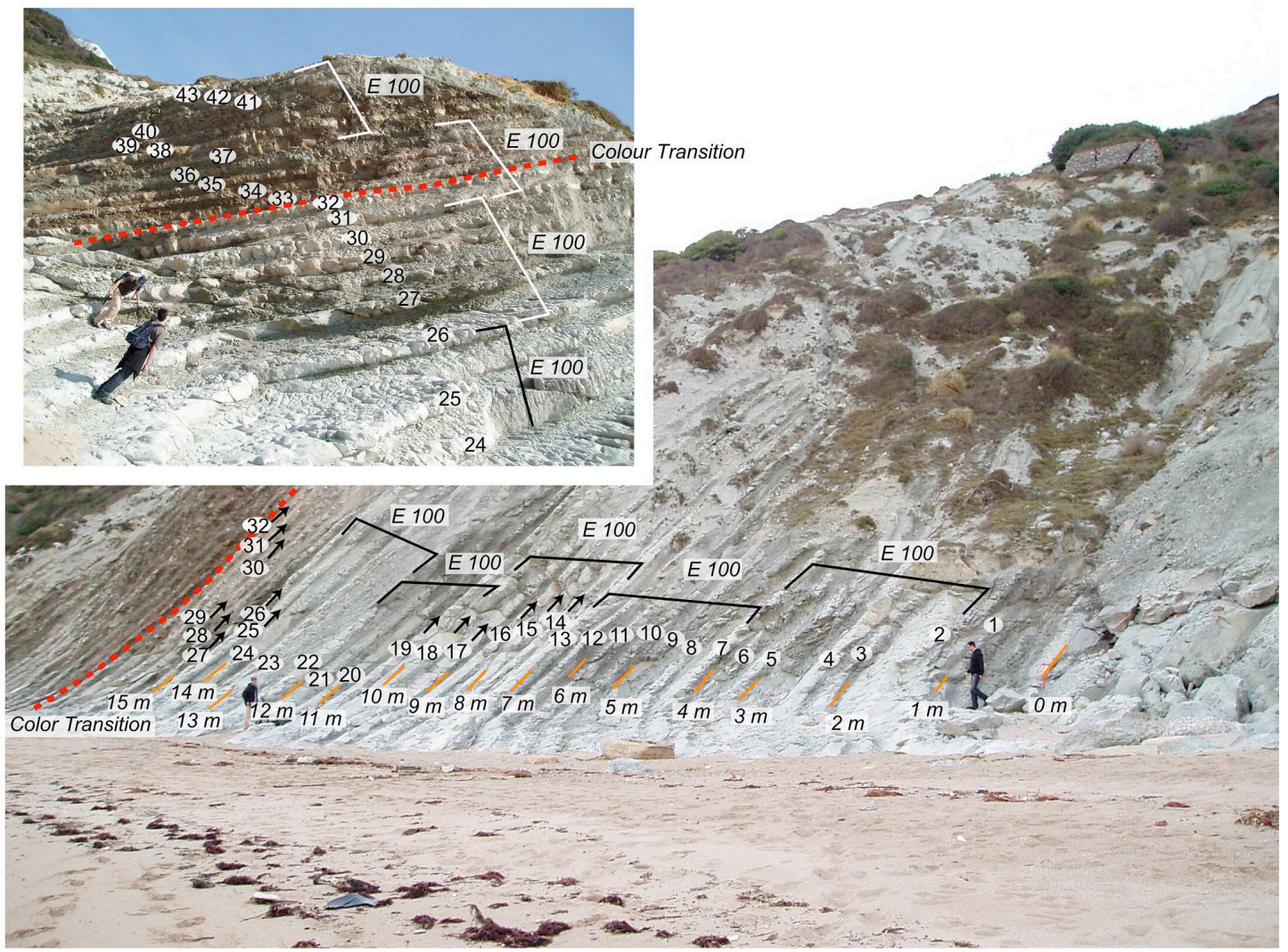

Fig. 2.

Photographs of the Bidart's limestone-marl couplets and of the colour transition dividing the section into two sub units. E100 $=100 \mathrm{kyr}$ eccentricity cycles. 
The studied sedimentary succession is subdivided in two sub-units (Fig. 2 and Fig. 3). The first sub-unit corresponds to decimetre to metre scale beds of grey-white marly limestone, in alternation with decimetre scale layers of dark grey argillaceous marl. The thickness of the calcareous layers decreases towards the top of this first sub-unit, whereas the marl layer thicknesses increase. The second sub-unit is characterised by decimetre scale layers of reddish marl, in alternation with decimetre scale layers of green to purple argillaceous marl. The thickness of the alternation tends to increase toward the top of the section, and the top of the calcareous layers often display several inoceramids. The transition between these sub-units is characterised by a blue-green to purple argillaceous layer situated at $17.9 \mathrm{~m}$, between the white calcareous layer 32, and the reddish calcareous layer 33 (Fig. 3). Small faults with minor offsets are common in the section (Fig. 3), rooted in the marl layers and sometimes running through the calcareous layers. The small offsets induced by these faults have been taken into account during sampling. Although some turbidites have been noted higher up in the Maastrichtian of Bidart (Clauser, 1994), no turbidites have been found in the studied interval.

Previous biostratigraphic studies (Clauser, 1994), dated the series to the upper Campanian. The magnetostratigraphic study of this section by Clauser (1994) cannot be used due to the poor preservation of the data and the low sampling resolution in the section studied here. Further calcareous nannofossil biostratigraphic study by Del Panta (1995) resulted in reassignment to an early Maastrichtian age, a conclusion that is refined in this study. A geochemical analysis of one calcareous marl couplet at the base of the section performed by Beltran et al. (2009) shows some contribution of allocthonous components in carbonate micro-particles.

\section{Methods}

\subsection{Magnetic susceptibility}

Magnetic susceptibility has been measured on 612 samples, using a Kappa bridge KLY-2, with a sampling step of $5 \mathrm{~cm}$ (Appendix A). Magnetic susceptibility (MS) measures the capacity of a substance to acquire magnetization when submitted to an external magnetic field. It is common in many marine sedimentary records that high frequency MS variations are directly related to relative terrigeneous supply, and therefore provide a useful palaeoclimatic proxy (Ellwood et al., 2000).

A significant change in the MS record takes place at about $3 \mathrm{~m}$ before the transition between the two sub-units, with the MS mean value increasing by about $10.10-8 \mathrm{~m} 3 / \mathrm{kg}$. (Fig. 3). The record obtained can thus be divided in two parts: (1) From 0 to $15 \mathrm{~m}$ MS values are low, with low frequency and low amplitude variations; (2) From 15 to $31.15 \mathrm{~m}$ MS values are higher and show higher amplitude and frequency variations. This could be due to a change in the clay mineralogy, possibly related to a shift in the source area of eroded material. 


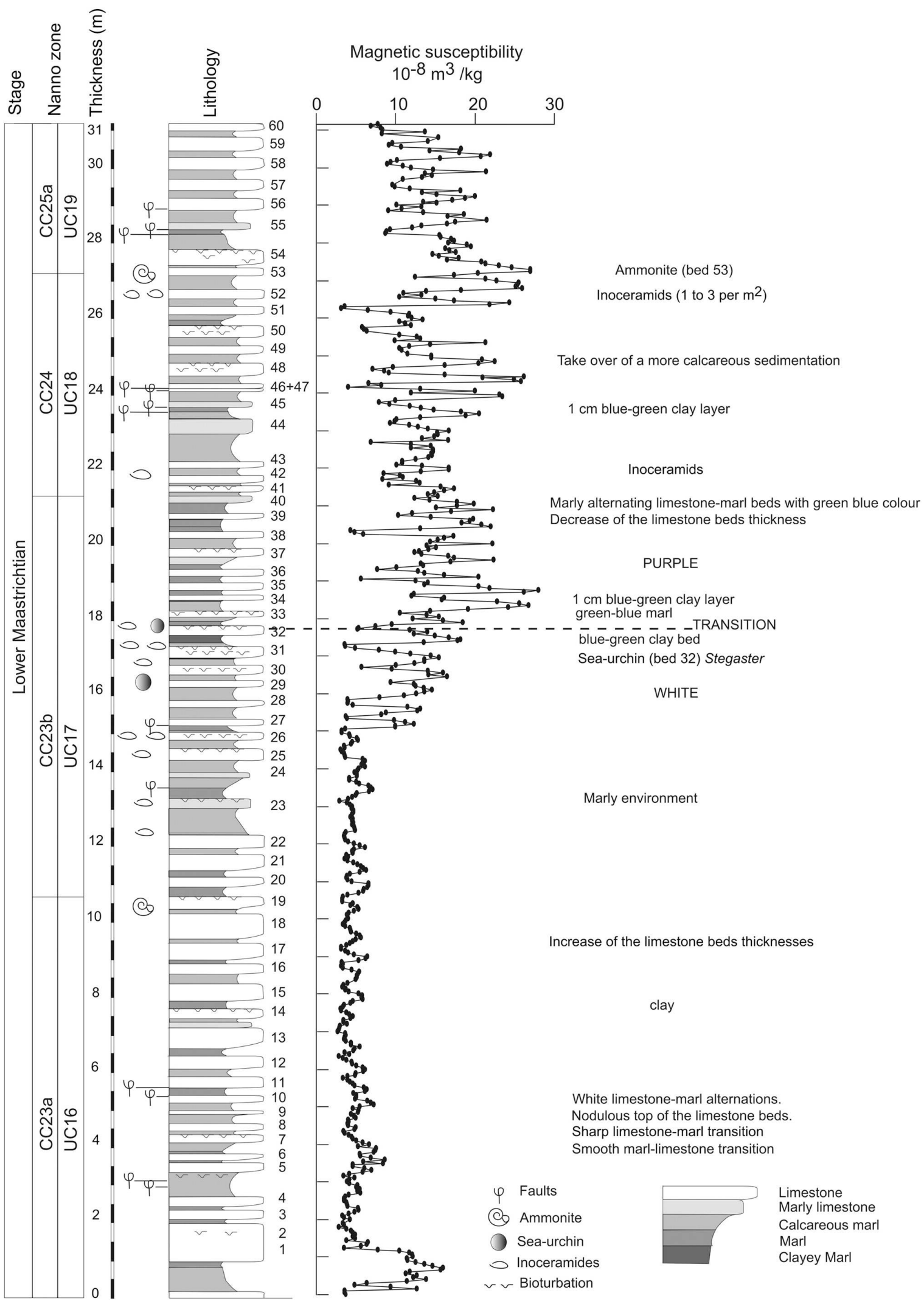

Fig. 3.

Detailed log of the lower Maastrichtian Bidart section, with magnetic susceptibility variations and samples analyzed for nannofossil biostratigraphy. Bidart limestones-marl alternations consist in two sub-units: a grey-to dark grey series with thick limestone and thin marl layers, followed by reddish to purple alternations of limestone and marl. The transition between the two sub-units occurs at $17.9 \mathrm{~m}$. Small faults with slight displacement are sometimes located within the marl layers. 


\subsection{Oxygen and carbon isotopes}

The oxygen and carbon isotopic composition of bulk carbonates were measured on a total of 221 samples, from marls and limestone layers and in several cases from each member (marl or limestone) of a couplet. (Appendix A). Isotopic analyses were performed on a SIRA9 mass spectrometer at the Laboratoire Biominéralisations et Environnements Sédimentaires (Université Pierre et Marie Curie, Paris 6, France). The CO2 was extracted by reaction of 5 to $10 \mathrm{mg}$ samples with anhydrous orthophosphoric acid at $50{ }^{\circ} \mathrm{C}$. The analytical precision was $0.05 \%$ for carbon and $0.09 \%$ for oxygen, calculated by repeated analyses of an internal standard calibrated against international standards NDS18 and NBS19. The oxygen and carbon isotope values are expressed in per mil relative to the V-PDB standard reference (Appendix A). The absence of correlation between carbon and oxygen stable isotopes, and the fact that measured $\delta 180$ values fall within the range of tropical-subtropical planktonic foraminifera for the lower Maastrichtian (Grossman, 2012), argue for well-preserved isotopic trends. For comparing these results with previous low-resolution isotopic data acquired by Clauser (1994) with different equipment and standards, we used a best fit of the two datasets with $a+0.1 \%$ re-standardization of Clauser's carbon and oxygen data.

\subsection{Nannofossil biostratigraphy}

Calcareous nannofossil biostratigraphy has been investigated on 18 samples (Fig. 4) following standard procedures of smear slide preparation. Key calcareous nannofossil biohorizons were quantified in 300 fields of view in order to better highlight possible reworked components that can affect the last occurrence (LO) of key species. This data acquisition is crucial for the studied time interval, which is punctuated by a succession of species disappearances. The identified bio-horizons, first occurrences (FOs) and LOs of key nannofossil species, allow the establishment of a biochronologic framework and correlation with the Tethyan Bottaccione and Contessa reference sections (Umbria Marche, Italy), which possess a sound magneto-biostratigraphic framework (Fig. 4).

\subsection{Signal processing}

The MS variations have been investigated using various signal processing tools. First, spectral analyses were performed using the multi taper method (MTM, Thomson, 1982). This method allows power leakage to be reduced by applying a small number of eigen tapers to the data, and performing a spectral analysis after each tapering. The mean of all the spectra obtained provides a periodogram with good frequency resolution. The frequency resolution is the ability of a method to detect with accuracy the exact frequency of a cycle, and to differentiate cycles with very close frequencies. A linear and a third-order polynomial detrending of the data has been applied prior to the analyses to suppress low frequency variations that could be related to long-term palaeoclimatic variations.

The method of frequency ratios (Mayer and Appel, 1999) was applied to test the link between the cycles highlighted by the spectral analysis and the orbital parameter variations, using orbital frequencies estimated for the Cretaceous (Berger and Loutre, 1994). Astronomical control of the sedimentation is inferred when the detected cycle frequency ratios are close to the orbital parameter ratios. 


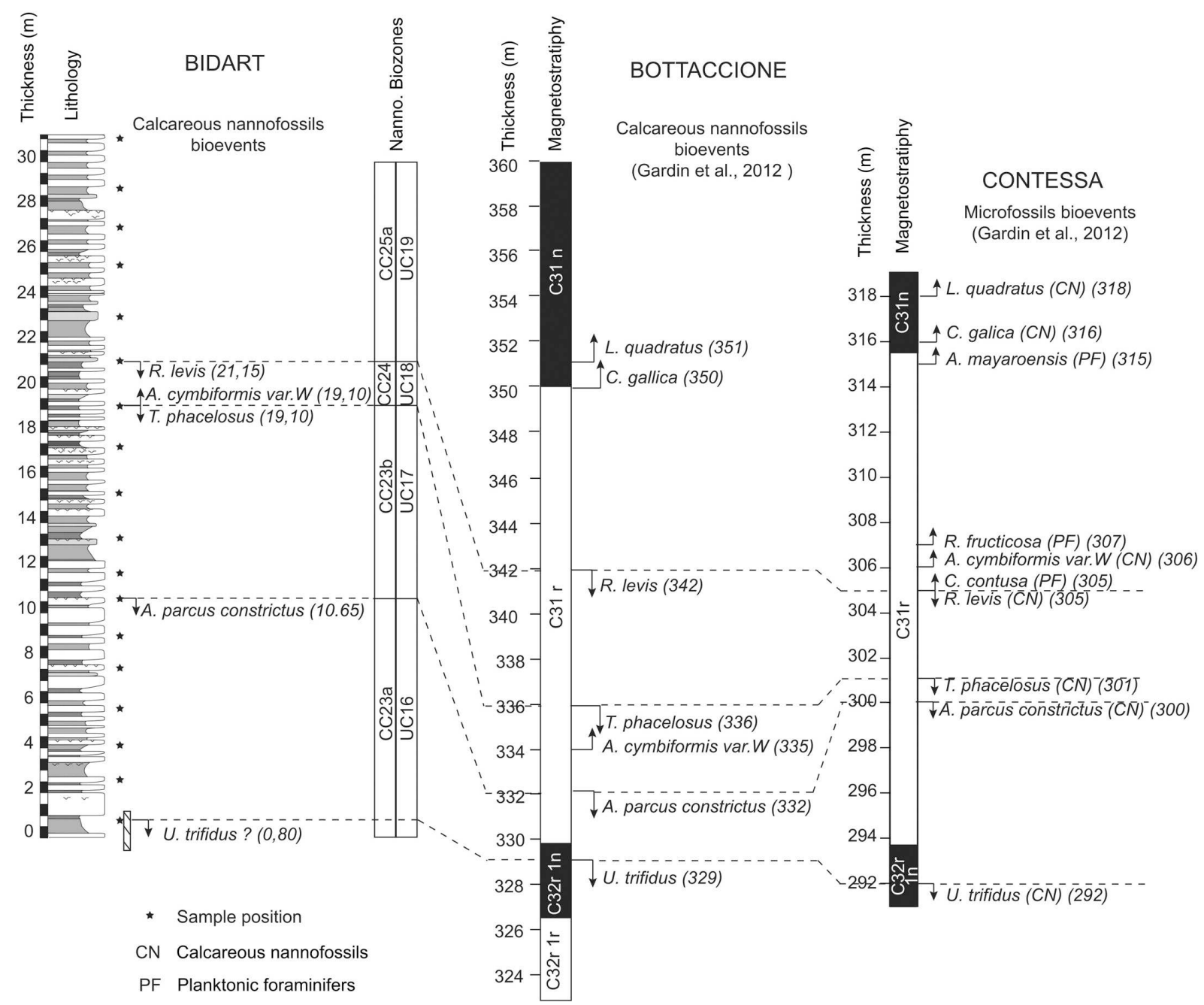

Fig. 4.

The correlation of nannofossil bio-events between Bidart and the Gubbio section allows dating of the sedimentary record to the lower Maastrichtian. The record partly covers chron C32n. $1 \mathrm{n}$ and a large part of C31r.

Every signal can contain some amount of red noise, linked to the effect known as persistence (i.e., correlation between the errors of the data) (Wilks, 1995). The red noise hypothesis has been tested by creating a new script especially designed for MatlabTM. This script is based on the work of Mudelsee (2002) and Schulz and Mudelsee (2002) and it evaluates the amount of red noise contained in the signal by using a simulation of red noise obtained through a Monte-Carlo loop. The new routine estimates the Monte-Carlo Markov Chains confidence levels, along with confidence levels based on a Chi-square test of the spectra of modeled red noise, and confidence levels based on Chi-square performed on the theoretical spectra of red noise. Only this last type of confidence level is presented here.

Spectral analyses have been completed using two time-frequency tools: the amplitude spectrogram method and wavelet analysis. These two methods allow the visualisation of cycles recorded through the sedimentary successions. They possess different properties of frequency and stratigraphic resolution. In general, stratigraphic resolution is proportional to the length of the interval studied: an analysis performed on a thick interval offers lower stratigraphic resolution than several thinner intervals.

The amplitude spectrogram method corresponds to a succession of spectral analyses, performed within a window sliding with a constant step along the record. The software used 
in this study employs the Fast Fourier Transform method for spectral analysis (Maurer et al., 2004). Each spectral analysis performed is plotted according to the position of the center of the window studied, and the power values are coded by a colour scale (red for a high power, blue for a low power). This technique illustrates timewise shifts in frequencies that result from variations of the sedimentation rates (Meyers et al., 2001; Maurer et al., 2004). The choice of the window size is very important as it influences the frequency resolution. A large window allows accurate detection of the high frequency cycles and the detection of low frequency cycles, but has low stratigraphic resolution. The step between each window affects the spatial resolution of the spectrogram. A compromise must therefore be found between frequency resolution and stratigraphic resolution. The software used in this study is a MatlabTM script by Maurer et al. (2004).

Wavelet analysis (Hubbard, 1996; Torrence and Compo, 1998) is an alternative approach based on the use of orthogonal functions called wavelets, the oscillations of which reach 0 after a short interval. The original record can be analysed using a family of wavelets, in the same way the sine and cosine waves are used in spectral analysis and amplitude spectrograms. For each application, a single shape of wavelet, or mother wavelet, is chosen. During the wavelet transform, the mother wavelet is stretched or compressed, allowing good detection of low and high frequency cycles, and it is shifted along the record. As for the amplitude spectrogram, the power of the cycles is represented by a colour scale. The software used here is the MatlabTM wavelet toolbox from Torrence and Compo (1998).

\section{Results}

\subsection{Biostratigraphic analysis}

The identified succession of calcareous nannofossil bio-horizons is reported in Figure 4 and Appendix B. A single specimen of Uniplanarius trifidus is found in the first sample studied $(0.8 \mathrm{~m})$ and thus it is not considered to represent a reliable bio-horizon. It is highly probable, in fact, that the LO of this taxon occurs lower in the section. The LO of Aspidolithus parcus constrictus is fixed around $10.65 \mathrm{~m}$, whereas the LO of Tranolithus phacelosus and the FO of Arkhangelskiella. cymbiformis var. W are located at $19.10 \mathrm{~m}$. Finally, the LO of Rheinardtites levis is fixed at $21.15 \mathrm{~m}$ (Fig. 4, Appendix B). The CC zonation of Sissingh (1977) modified by Perch-Nielsen (1985) and the UCTP zonation of Burnett (1998) are applied ( Fig. 3, Fig. 4, Fig. 5, Fig. 6, Fig. 7, Fig. 8, Fig. 9 and Fig. 10). The calcareous nannofossil biohorizons identified at Bidart can be correlated with those of the Gubbio reference sections that lie in the middle of chron C31r (Fig. 4) (Gardin et al., 2012). According to this correlation, the sedimentary succession studied here should cover at least the first half of Chron C31r.

\subsection{Cyclostratigraphic analysis}

The initial cyclostratigraphic analysis is performed on the MS data, sampled with the highest resolution, in order to detect a potential astronomical forcing of the sedimentation (Fig. 5). The sharp increase in magnetic susceptibility values at $15 \mathrm{~m}$ affects the cyclostratigraphic analyses and has been minimized by converting the data to a log scale. Spectral analysis performed on the entire record shows significant power for wavelengths ranging from 0.44 to $8.55 \mathrm{~m}$ (Fig. 5A). Typical hemipelagic sedimentation rates of 0.5 to $1.0 \mathrm{~cm} / \mathrm{kyr}$ place these signals in the orbital band. If an average sedimentation rate for the section is assumed such that the prominent peak at $0.44 \mathrm{~m}$ matches the shortest quasi-period of precession (e.g., $0.45 \mathrm{~cm} / \mathrm{kyr}$ ), then signals at $2.44 \mathrm{~m}$ and $8.55 \mathrm{~m}$ correspond to periods very similar to published Cretaceous examples of short and long eccentricity, respectively (Sageman et al., 1997). The strength of the three signals matching the predicted ratios of orbital cycles is taken as a strong support for the proposed average sedimentation rate. It is also possible, however, that the $8.55 \mathrm{~m}$ cycle may be an artifact related to the step in MS values. 

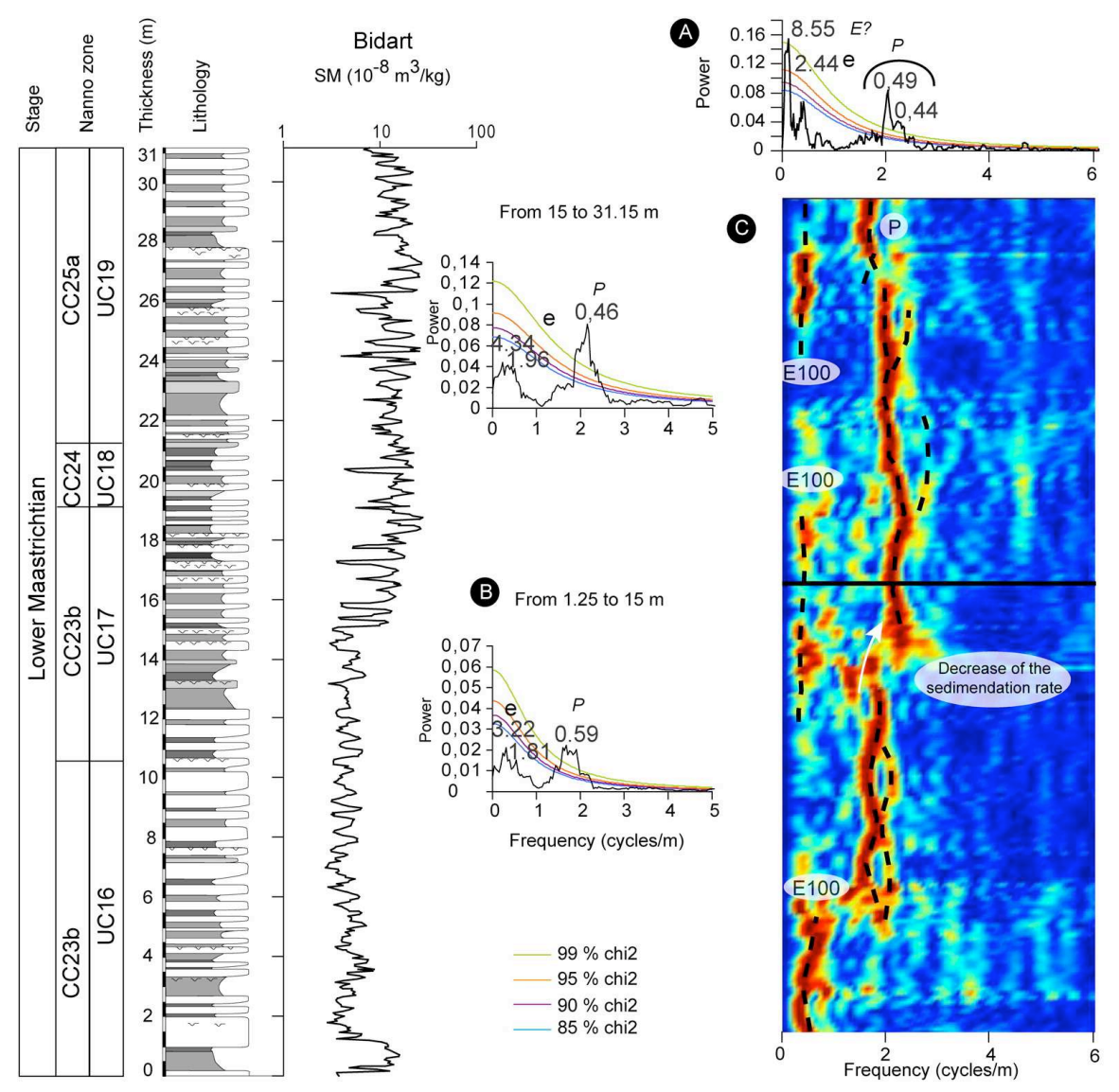

c
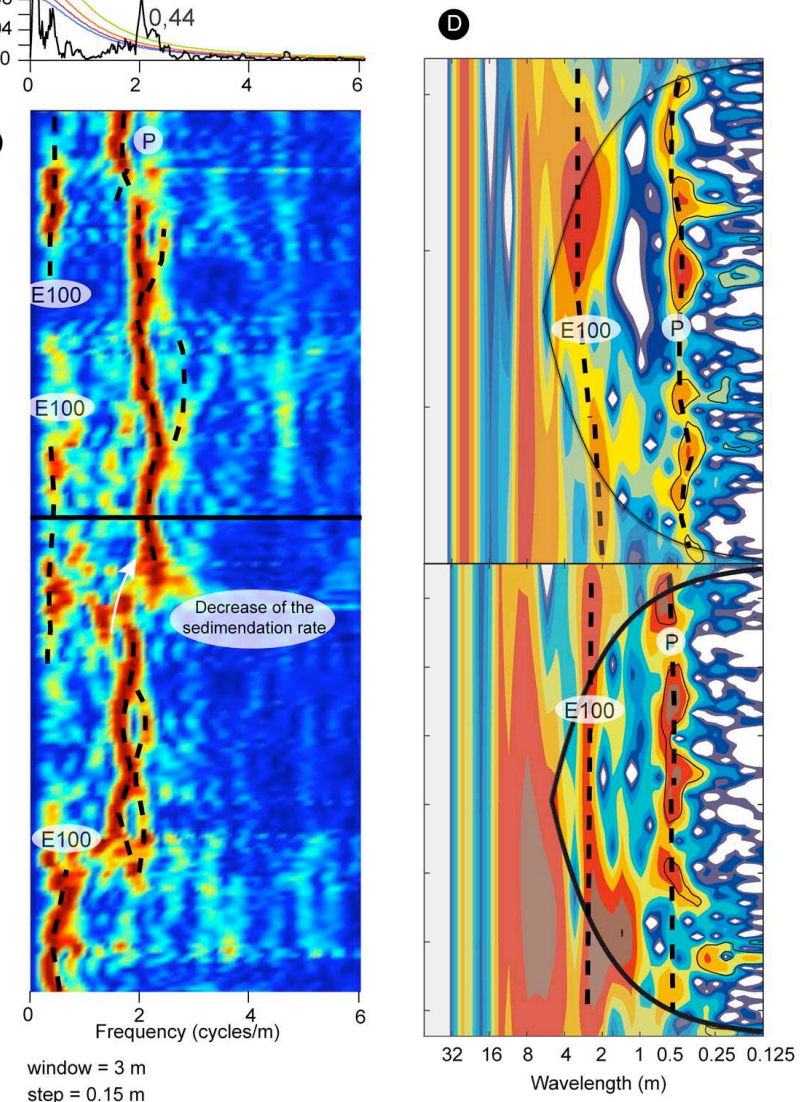

Fig. 5.

Cyclostratigraphic analysis of the MS variations from Bidart section. MS values are presented in a logarithmic scale. A) Spectral analysis of the entire record in log scale with the MTM method highlights a powerful peak above the $99 \%$ confidence level corresponding to the precession. Eccentricity power is lower, but reaches the $85 \%$ confidence level. B) Two spectral analyses performed from $1.25 \mathrm{~m}$ to 15 $\mathrm{m}$ and 15 to $31.15 \mathrm{~m}$ confirms the interpretation of $(\mathrm{A})$, and a strong signal of the precession compared to the eccentricity. The two amplitude spectrograms (C) and wavelet analysis (D) show evolution of the precession similar to the theoretical evolution of this parameter, indicating the high quality of the precession record in the Bidart section. These plots also show a decrease in sedimentation rate at $13.5 \mathrm{~m}$.

To isolate the intervals above and below this step, spectral analyses are performed on the first and second half of the MS record (Fig. 5B). Cycles with significant power at wavelengths of 0.59 and $0.46 \mathrm{~m}$ are highlighted in the resulting periodograms. Based on the spectra for the entire section, discussed above, these are hypothesized to reflect precession cycles. The $0.59 \mathrm{~m}$ cycle from the lower interval $(1.25-15 \mathrm{~m})$ shows a slight division into two peaks, consistent with the multiple quasi-periods of precession that are commonly recognized in power spectra (Fig. 5B). Peaks with wavelengths of 1.81 (lower interval) and $1.96 \mathrm{~m}$ (upper interval) are also observed in the spectra (Fig. 5B), and would be consistent with the $100 \mathrm{kyr}$ eccentricity cycle (Fig. 5B).

Stratigraphically, the dominant recorded frequencies shift slightly in the evolutive amplitude spectrograms of the lower and upper interval (Fig. 5C), suggesting minor changes in sedimentation. This is confirmed by wavelet analysis performed on the same intervals (Fig. 5D). The spectrograms and the wavelet analysis both detect cycles interpreted as precession and $100 \mathrm{kyr}$ eccentricity, in agreement with prior spectral analyses. Precession cycles present a bundling on the wavelet analysis, and a powerful trend is highlighted by the amplitude spectrogram (Fig. 5C). The amplitude spectrogram between 6 and $15 \mathrm{~m}$ shows 
two successive bifurcations of the precession signal. Very similar variations are observed in the theoretical evolution of the second mode of the precession extracted from astronomical solutions (Appendix C). Nevertheless, this division may not mirror the theoretical signal, but could instead be triggered by sedimentation rate variations. Although this feature of the precession is modulated by the $405 \mathrm{kyr}$ eccentricity in the astronomical solution, the bifurcations in the Bidart section cover a length of about $100 \mathrm{kyr}$. The presence of minor hiatuses has been shown to produce similar bifurcations in the obliquity signal in late Cenomanian evolutive amplitude spectra (Meyers and Sageman, 2004).
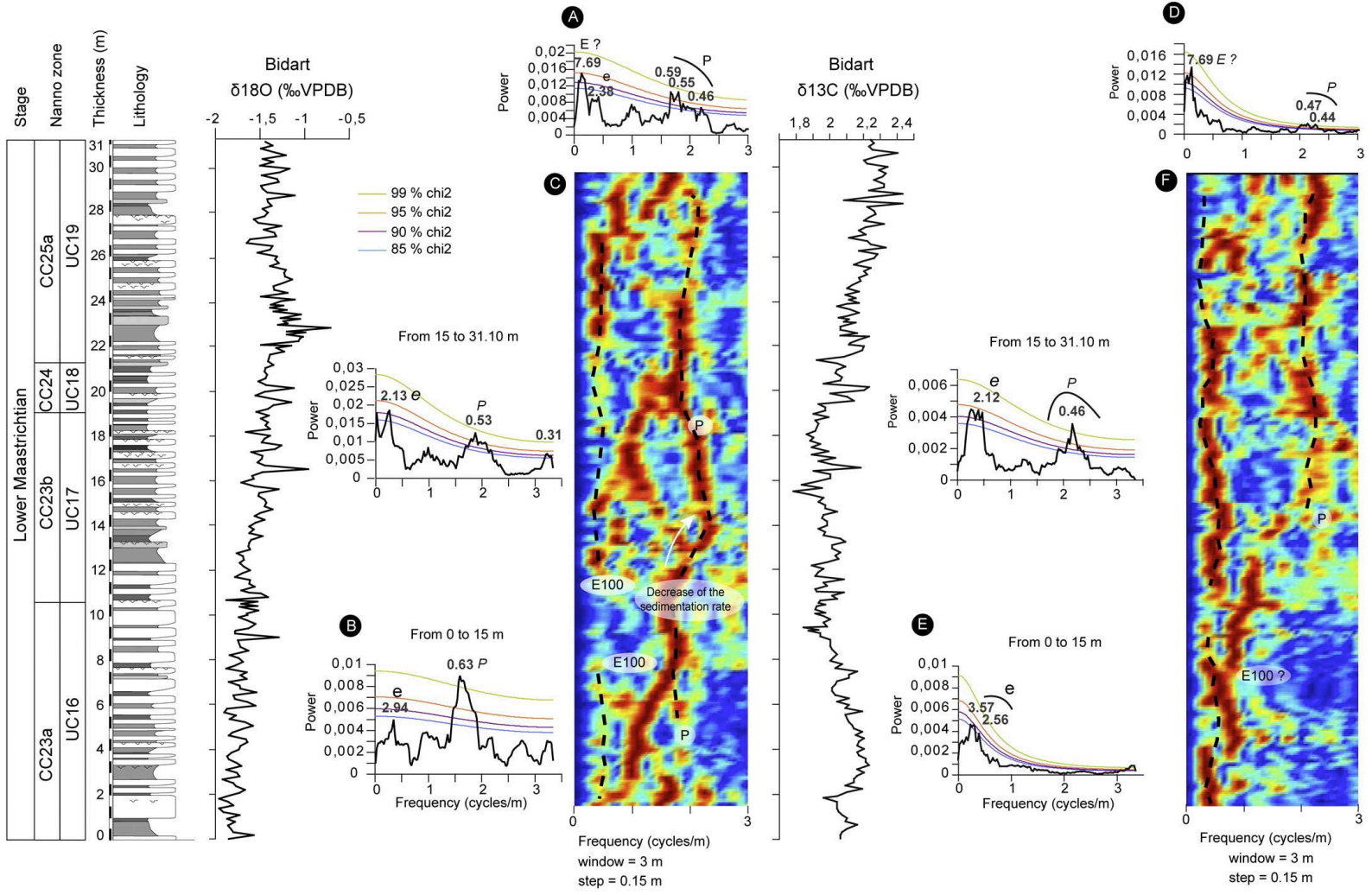

Fig. 6.

Cyclostratigraphic analysis of $\delta^{18} \mathrm{O}$ and $\delta^{13} \mathrm{C}$ from the Bidart section. A) Spectral analysis of the entire $\delta^{18} \mathrm{O}$ highlights a powerful peak interpreted as precession forcing and less powerful $100 \mathrm{kyr}$ eccentricity cycles. B) Two spectra on shorter intervals confirm the good record of precession, and indicate a better record of the 100 kyr eccentricity in the upper part of the section. C) The amplitude spectrogram shows a powerful trend corresponding to the precession, the $100 \mathrm{kyr}$ eccentricity being discontinuous. D) Spectral analysis of the entire $\delta^{13} \mathrm{C}$ signal shows that orbital forcing is weaker on this dataset, compared to $\delta^{18} \mathrm{O}$ and MS. No peaks are clearly visible, although small peaks above the $99 \%$ confidence level could correspond to the precession. E) Two spectral analyses on shorter intervals indicates a rather poor record of the orbital parameters by the $\delta^{13} \mathrm{C}$ from 0 to $15 \mathrm{~m}$, whereas the upper part of the section presents a very good record of the precession (above $99 \%$ confidence level) and the eccentricity (reaching 95\% confidence level). This discrepancy is confirmed by trends observed on the amplitude spectrogram (F).

Cyclostratigraphic analysis of the $\delta 180$ signal allows detection of cycles with wavelengths of $0.46 \mathrm{~m}$ to $0.59 \mathrm{~m}$, with a very high power, in agreement with the cycles observed in the MS signal (Fig. 6A). Two spectra from shorter intervals confirm this result (Fig. 6B). Moreover, a cycle with high power and a wavelength of $2.13 \mathrm{~m}$ to $2.94 \mathrm{~m}$ is detected. This cycle reaches more than $90 \%$ confidence in the upper part of the record. A division of the $0.46 \mathrm{~m}$ cycle into two peaks can be observed between $10 \mathrm{~m}$ and $18 \mathrm{~m}$ on the amplitude spectrogram, likely due to a perturbation of the sedimentation in this interval (Fig. 6C). As shown by Meyers and Sageman (2004), small hiatuses and small sedimentation rate variations can induce 
bifurcations of cycles expressed on evolutive amplitude spectrum. Although this cycle is present throughout most of the studied interval, the spectrogram in Figure $6 \mathrm{C}$ shows that the $2.13 \mathrm{~m}$ cycle that occurs with high power in the upper half of the section is less persistent.

Spectral analysis of the entire $\delta 13 \mathrm{C}$ signal shows that orbital forcing has weaker expression in this dataset, compared to $\delta 180$ and MS. Only small peaks with wavelengths of 0.44 to $0.47 \mathrm{~m}$ reaching the $99 \%$ confidence level (Fig. 6D) are detected. Analysis of the upper half of the section (Fig. 6E) shows a more significant response for the cycle with wavelength of $0.46 \mathrm{~m}$. The amplitude spectrogram performed on the series confirms the strong expression of this cycle in the upper Maastrichtian (Fig. 6F). Periodograms for both the lower and upper intervals (Fig. 6E) show significant power for a cycle with wavelength from $2.12 \mathrm{~m}$ to $2.84 \mathrm{~m}$, as also observed in MS and $\delta 180$ analyses. In the periodogram for the upper half of the $\delta 13 \mathrm{C}$ record (Fig. 6E) this cycle, interpreted as the short eccentricity peak, reaches a $95 \%$ confidence level. The $100 \mathrm{kyr}$ eccentricity is thus recorded by 3 different proxies, with $\delta 13 \mathrm{C}$ providing a response with a high confidence. When cycles with wavelength of $0.47 \mathrm{~m}$ are interpreted as precession, the $2.12 \mathrm{~m}$ to $2.84 \mathrm{~m}$ cycles correspond very well with a $100 \mathrm{kyr}$ eccentricity signal. The relatively low power of the $100 \mathrm{kyr}$ eccentricity peak compared to the precession in MS and $\delta 180$ records could reflect a dominance of precession forcing in these proxies, while $\delta 13 \mathrm{C}$ may be relatively more sensitive to $100 \mathrm{kyr}$ eccentricity forcing. The absence of the eccentricity peak in the periodogram for the entire $\delta 13 \mathrm{C}$ signal could be due to power leakage toward the lower frequencies induced by long term variations. These analyses provide strong evidence for an excellent record of an astronomical control of the sedimentation by the precession, visually expressed here in marl-limestone alternations (Fig. 2 ), whose thicknesses consistently match the 0.4 to $0.6 \mathrm{~m}$ wavelengths identified in $\delta 180$ and MS throughout the section. Comparatively, a relatively weak influence of the $100 \mathrm{kyr}$ eccentricity is recorded in climate proxies but is hard to identify visually in the field, along with amplitude variations that could be related to the $405 \mathrm{kyr}$ eccentricity cycles (Fig. 2). The MS variations present a better record of the $100 \mathrm{kr}$ eccentricity cycles than the lithology, emphasizing the importance of performing physical measurements on lithologically alternating series.

\subsection{Sedimentation rate variations}

The Bidart record is characterized by a distinct shift of the precession signal toward higher frequency, as observed in the evolutive amplitude spectrum for MS (Fig. 5C). This shift indicates a decrease of the sedimentation rate from about $13 \mathrm{~m}$ to the top of the section, and this decrease is reflected in the decreased thickness of limestone-marl couplets. The change is abrupt, as indicated by the discontinuity of cycles at $13 \mathrm{~m}$ on the amplitude spectrogram (Fig. 5C). In addition, a slow shift of the precession toward the lower frequencies is visible between 23 and $29.5 \mathrm{~m}$ on the amplitude spectrogram and wavelet analysis, corresponding to a slight increase in sedimentation rate. Precession cycles in the $\delta 180$ record also clearly express the decrease in the sedimentation rate on the amplitude spectrogram, with a shift toward the higher frequencies at $12 \mathrm{~m}$. The shift is not detected in the lower part of the $\delta$ $13 \mathrm{C}$ signal, were the record of the precession is weaker. 


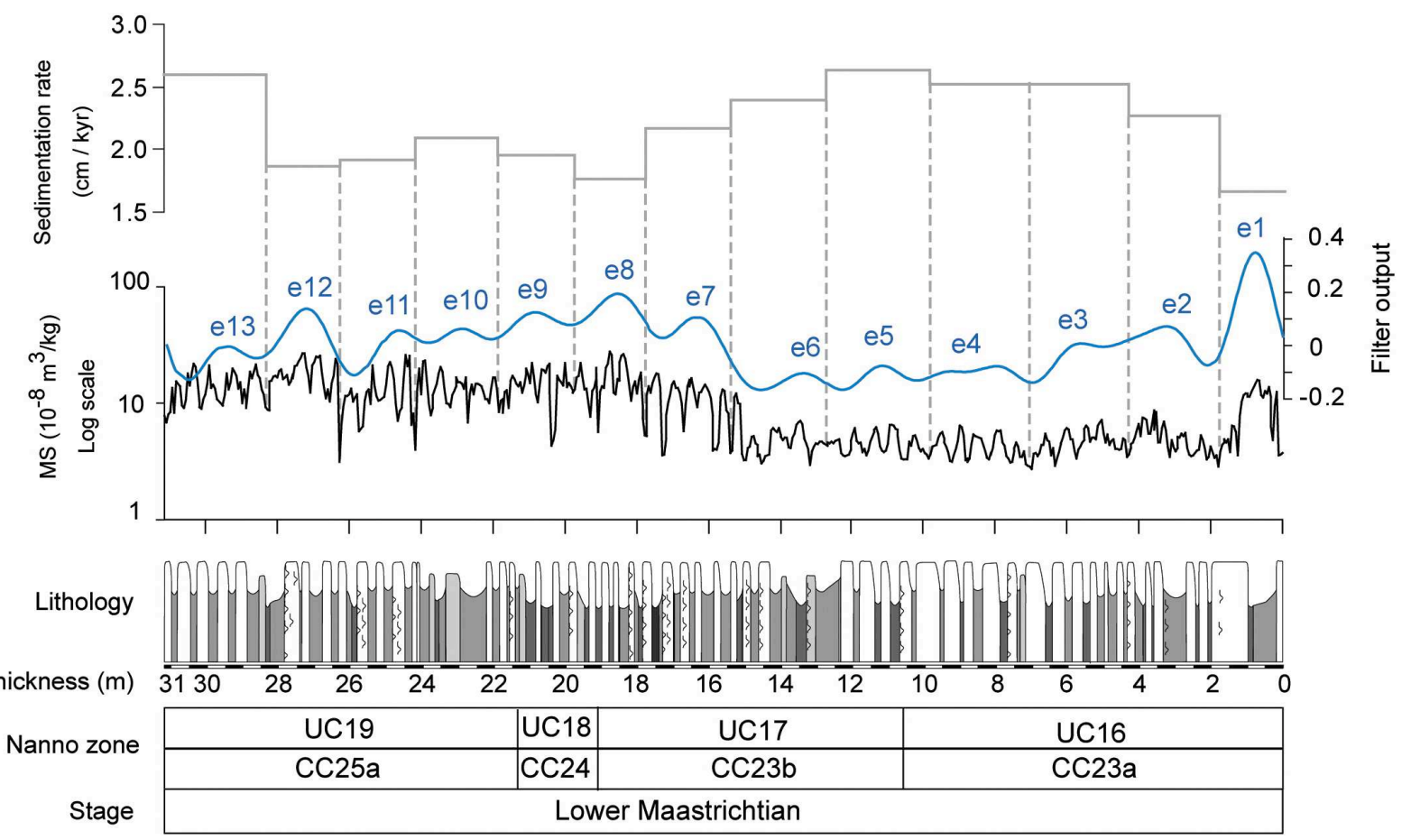

Fig. 7.

Cyclostratigraphic framework of the lower Maastrichtian in the Bidart section. The blue curve illustrate the $100 \mathrm{kyr}$ eccentricity cycles filtered from the data using a Taner Filter (Taner, 2000). Sedimentation rate variations have been taken into account as much as possible during filtering. The duration represented by the section is estimated to $1.44+/-0.22$ Myr by counting precession and $100 \mathrm{kyr}$ eccentricity cycles, which is consistent with the biostratigraphic correlation to Gubbio sections (Italy). Sedimentation rate variations are estimated at the scale of the $100 \mathrm{kyr}$ cycles, and plotted in grey. The sedimentation rate is considered constant during a $100 \mathrm{kyr}$ cycle, and the length of the segments corresponds to the length of the cycles. Grey dashed lines correspond to the boundaries of the cycles identified.

\section{Discussion}

\subsection{Construction of a relative timescale}

A relative time scale can be constructed based the $100 \mathrm{kyr}$ eccentricity cycles identified using the results of the cyclostratigraphic analysis (Fig. 7). A filter applied afterwards on the scaled data illustrates the identified $100 \mathrm{kyr}$ cycles. This time scale allows a test of the reliability of orbital cycle identifications (Appendix D), and an estimation of the duration represented by the section. The more stable $405 \mathrm{kyr}$ eccentricity cannot be used here, due to the short length of the section and resulting uncertainties in the identification of this cycle. Constructing a timescale based on $100 \mathrm{kyr}$ eccentricity cycles results however in more uncertainty than the $405 \mathrm{kyr}$ eccentricity and obliquity cycles. Indeed, the short eccentricity cycle is a combination of several modes, with periods ranging today from 95 to $128 \mathrm{kyr}$ (Hinnov, 2000). In the Cretaceous, it is not yet possible to know whether an eccentricity cycle recorded in a sedimentary series corresponds to a $\sim 95$ or a $~ 128 \mathrm{kyr}$ eccentricity cycle (Hinnov, 2000, Figure 15, Laskar et al., 2004). Thus, each cycle identified here is interpreted to have an average period of $111 \mathrm{kyr}$, the mean of the two main short eccentricity modes with an uncertainty of $+/-17 \mathrm{kyr}$ equal to the difference from this mean period to the two modes. Uncertainties on durations presented here are estimated based on the number of cycle identified time the uncertainty on each cycle. The zero level of the relative time scale is situated at the top of the section. Temporal values are attributed to the boundaries of each identified short eccentricity cycle, starting from 0 and increasing with a $111 \mathrm{kyr}$ step. The relative age of each point between the boundaries is then interpolated. A new relative time- 
scale is thus built, allowing sedimentation rate variations to be corrected at the scale of the 100 kyr eccentricity.

Spectral analysis of the scaled record highlights a powerful spectral peak with periods of 24 and $22 \mathrm{kyr}$ that match very well with the frequencies of the two modes of the precession, thus confirming the exceptional record of this parameter in the Bidart section (Appendix D). Cycles with a period of $416 \mathrm{kyr}$ could correspond to the $405 \mathrm{kyr}$ eccentricity cycles, the expression of which could be enhanced by the scaling.

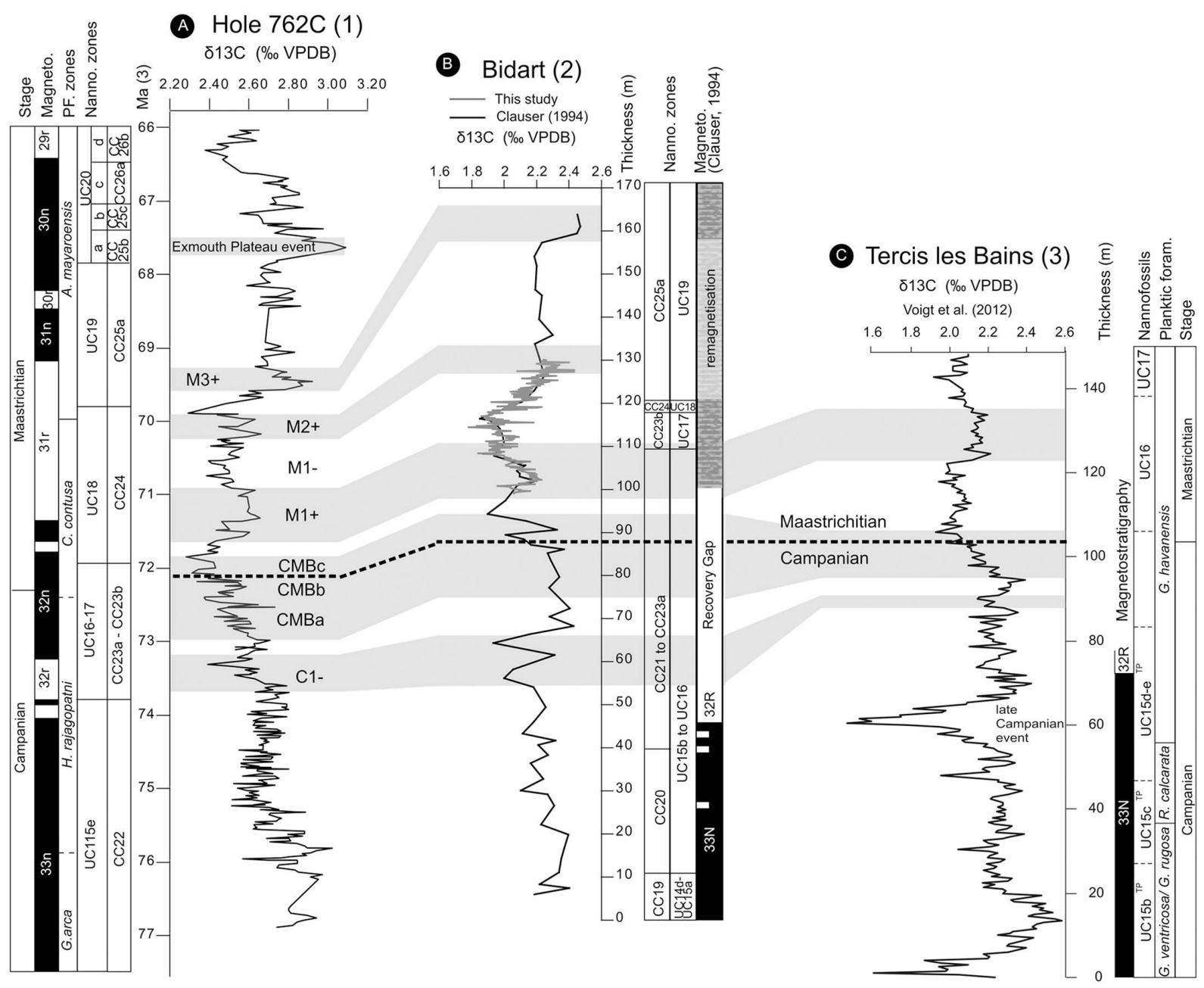

Fig. 8.

Correlation of $\delta 13 \mathrm{C}$ curves between Bidart, Tercis les Bains and the astronomically calibrated ODP Hole 762C. A) Correlation of the Clauser (1994) $\delta 13 \mathrm{C}$ record from Bidart to ODP Hole $762 \mathrm{C}$ and Tercis les Bains allows identification of major isotopic events. B) Correlation of Bidart and ODP Hole $762 \mathrm{C}$ indicates that the base of Bidart signal can be dated to $\sim 76.6 \mathrm{Ma}$, within chron C33n C) Correlation of Clauser (1994) data to the Tercis les Bains and Hole 762C record shows that the Campanian-Maastrichtian boundary would be situated at $\sim 86 \mathrm{~m}$ in the Bidart section. (1) The updated astronomically calibrated $\delta 13 \mathrm{C}$ curve of Hole $762 \mathrm{C}$ has been compiled from data of Thibault et al. (2012a) and Stoll and Schrag (2001) (Appendix E). Nannofossils biostratigraphy is from Thibault et al. (2012), magnetostratigraphy from Thibault et al (2012) and Galbrun (1992), Planktonic foraminiferal (PF) zonation from Zepeda (1998). All stratigraphic informations available for ODP Hole 762C can be retrieved in Thibault et al. (2012a). 2) Magnetostratigraphy and nannofossil biostratigraphy from Bidart section are from Clauser (1994) and this study. Remagnetized data in the lower Maastrichtian are represented by a grey interval (3) Planktonic foraminiferal and nannofossil biostratigraphy of the Tercics les Bains section is from Voigt et al (2012). 


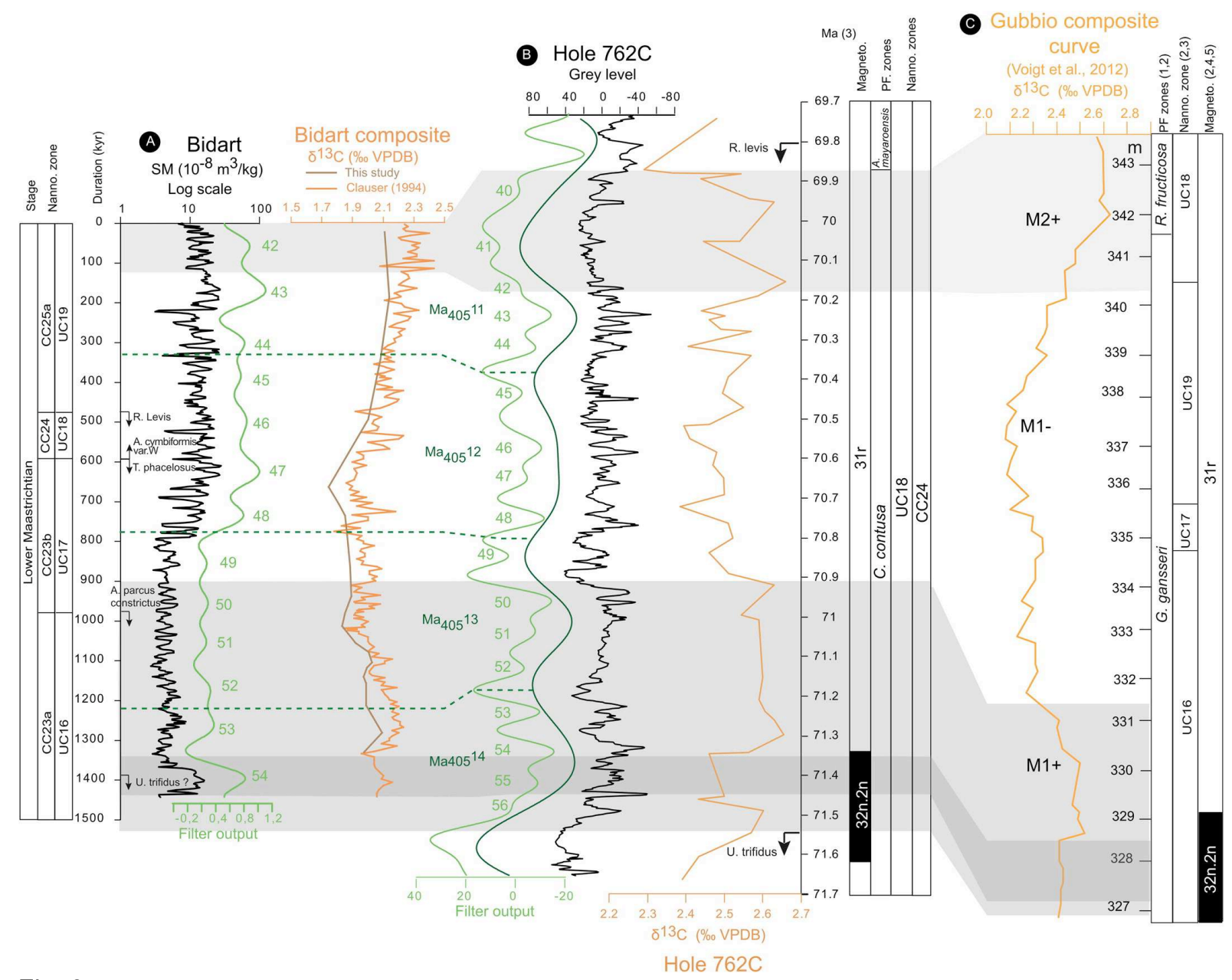

Fig. 9.

Correlation of $\delta 13 \mathrm{C}$ and MS from Bidart to $\delta 13 \mathrm{C}$ and grey level variations of the astronomically calibrated ODP Hole $762 \mathrm{C}$ and Gubbio sections. A) Correlation of the $\delta 13 \mathrm{C}$ signal between Bidart and ODP Hole $762 \mathrm{C}$ shows that the studied interval extends from $71.5 \mathrm{Ma}$ to $70 \mathrm{Ma}$, and covers short eccentricity cycles E10042 to E10054. The studied interval covers Chron C32n.1n and about 2/3 of C31r. B) Major isotopic events M1 +, M1- and M2 + can be recognized at Bidart, ODP Hole 762C and Gubbio sections. M1- event duration is estimated to $800 \mathrm{kyr}$ both from Bidart and Hole 762C. C) Correlation of Bidart and ODP Hole 762C cyclostratigraphic results allow positioning of $405 \mathrm{kyr}$ cycle boundaries at $\sim 320, \sim 780$ and $\sim 1220 \mathrm{kyr}$ in the studied interval. References: (1) Premoli Silva and Sliter (1995), (2) Gardin et al. (2012), (3) Monechi and Thiersten (1985), (4) Arthur and Fischer (1977), (5) Lowrie and Alvarez $(1977,1981)$.

An amplitude spectrogram performed on the scaled data indicates that the sedimentation rate variations have been successfully corrected at the $100 \mathrm{kyr}$ eccentricity scale, since the precession signal is now nearly continuous and without significant changes in frequency (Appendix D). Sedimentation rate still varies at the precession scale, as this parameter has not been constrained by the scaling.

The duration represented by the section has been estimated at $1.44+/-0.22$ Myr by counting short eccentricity cycles. This duration is lower than the estimate of $2.09+/-0.03$ for the entire chron C31r (Husson et al, 2012), which is coherent with the biostratigraphic data. The duration of the interval between two bio-events, the LOs of $U$. trifidus and R. levis, can be estimated to be at least $0.91+/-0.13 \mathrm{Myr}$ (Fig. 7), which is similar to its temporal estimate in the Contessa section (Husson et al., 2012; Gardin et al., 2012). Therefore, the recorded LO of U. trifidus, based on only one occurrence at the base of the section, may actually be accurate. 


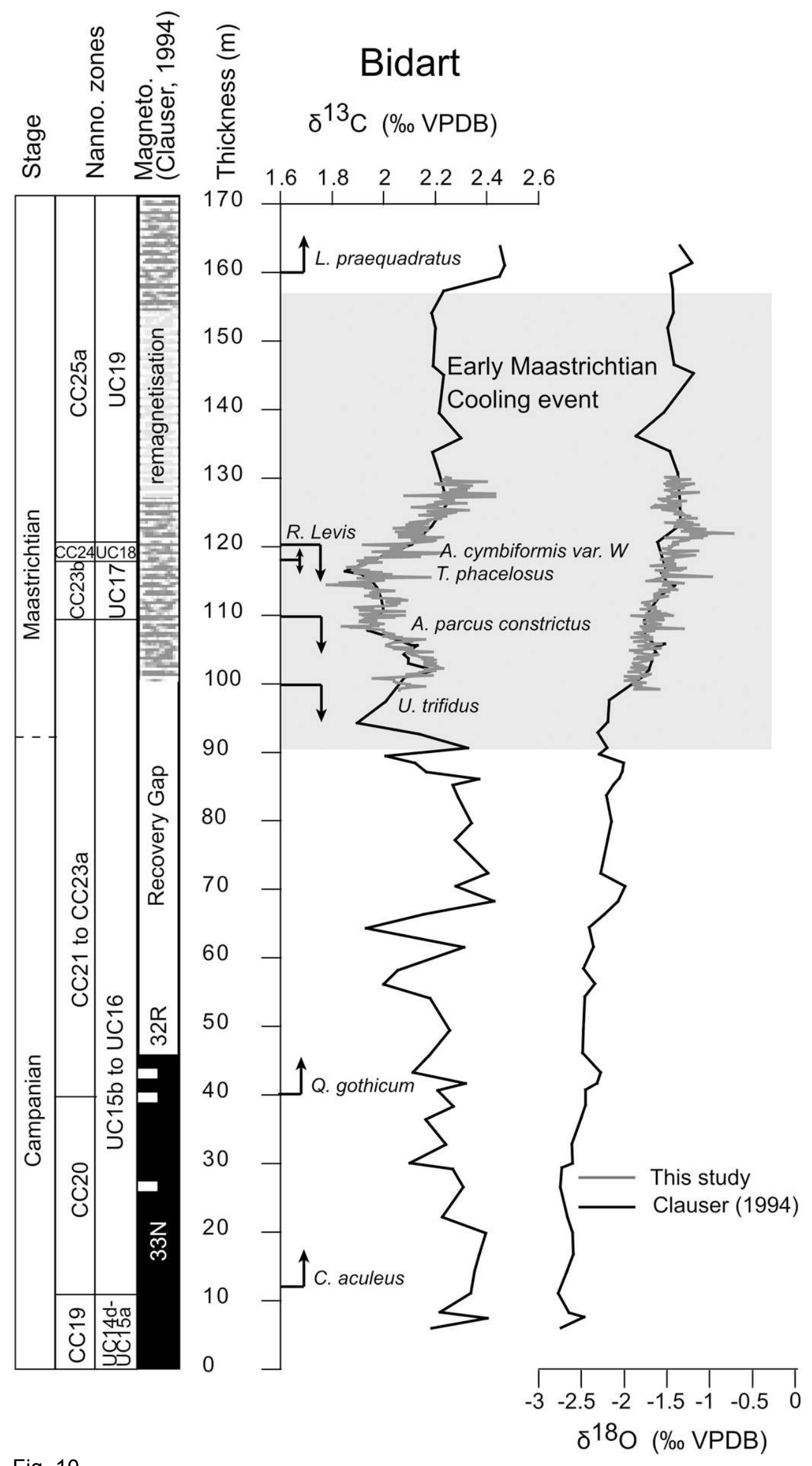

Fig. 10.

Upper Campanian to mid-Maastrichtian stratigraphy, carbon and oxygen isotope data of Clauser (1994) and this study for the Bidart section. 
To test the reliability of this new timescale, we compared the sedimentation rate implied by our relative time scale to the sedimentation rate obtained through correlation to the Bottaccione and Contessa section (Fig. 4). Gardin et al. (2012) proposed synthetic Tethyan reference ages for the LOs of $A$. parcus constrictus and R. levis. The duration separating these events has been estimated from 516 to $1185 \mathrm{kyr}$ (Gardin et al., 2012). In the Bidart section, the LO's of A. parcus constrictus and R. levis are separated by $10.5+/-3$. $1 \mathrm{~m}$. Assuming a duration similar to the durations obtained in the Gubbio reference sections, the sedimentation rate in Bidart between these two bioevents would range between 0.6 and 2.6 $\mathrm{cm} / \mathrm{kyr}$. The mean sedimentation rate inferred using our cyclostratigraphic approach is $2.1+/-$ $0.6 \mathrm{~cm} / \mathrm{kyr}$ between the LOs of A. parcus constrictus and R. levis. Thus the relative timescale built for Bidart is in agreement with observations from the Tethyan reference sections. A relative time-scale has also been constructed for the $\delta 180$ and $\delta 13 \mathrm{C}$ records based on the MS age model. The Bidart scaled carbon isotope record is correlated to the astronomically calibrated $\delta 13 \mathrm{C}$ record of ODP hole $762 \mathrm{C}$, allowing estimation of the age of the section.

\begin{tabular}{|c|c|c|c|c|c|c|c|}
\hline Bioevents & $\begin{array}{l}\text { Top depth } \\
(\mathrm{m})\end{array}$ & $\begin{array}{l}\text { Bottom } \\
\text { depth (m) }\end{array}$ & $\begin{array}{l}\text { Top depth } \\
\text { (Ma) }\end{array}$ & $\begin{array}{l}\text { Bottom depth } \\
\text { (Ma) }\end{array}$ & Age (Ma) & $\begin{array}{l}\text { Uncertainty on } \\
\text { bioevents } \\
\text { positions (Ma) }\end{array}$ & $\begin{array}{l}\text { Total } \\
\text { uncertainty } \\
\text { (Ma) }\end{array}$ \\
\hline FO N. frequens & 25.4 & 23.1 & 70.48 & 70.64 & 70.56 & 0.08 & 0.15 \\
\hline LO R. levis & 23.1 & 21.15 & 70.64 & 70.75 & 70.695 & 0.055 & 0.125 \\
\hline LO E. eximius & 17.4 & 15.2 & 70.88 & 70.99 & 70.935 & 0.055 & 0.125 \\
\hline LO C. obscurus & 15.2 & 13.3 & 70.99 & 71.06 & 71.025 & 0.035 & 0.105 \\
\hline LO A. parcus constrictus & 11.8 & 10.65 & 71.12 & 71.19 & 71.155 & 0.035 & 0.105 \\
\hline LO A. parcus parcus & 11.8 & 10.65 & 71.12 & 71.19 & 71.155 & 0.035 & 0.105 \\
\hline
\end{tabular}

Table 1.

Estimation of Bidart's bio-events ages based on the correlation of Bidart section to ODP Hole 762C. Total uncertainty correspond to the sum of the uncertainty inherent to the bio-event position and the uncertainties linked to the correlation to the astronomically calibrated ODP Hole $762 \mathrm{C}$, including the uncertainty on the radiogenic dating of the Cretaceous-Paleogene boundary from Renne et al. (2013).

\subsection{Correlation to reference sections and age estimation}

The new isotopic data from this study can be correlated with the low-resolution carbon isotopic data published by Clauser (1994). Values and trends match well between Clauser's restandardized data and this new dataset (Fig. 8.B). Compilation of the two datasets allows correlation to the astronomically calibrated $\delta 13 \mathrm{C}$ signal of ODP hole 762C (Fig. 8A), and to the section of Tercis les Bains, Global Standard Section and Point (GSSP) of the Campanian-Maastrichtian boundary (Fig. 8C). A timescale for ODP Hole 762C $\delta 13 \mathrm{C}$ has been constructed by Thibault et al. (2012a), based on the identification of $100 \mathrm{kyr}$ cycles, and adapted from the second astronomical calibration option of Husson et al. (2011).

The major isotopic events $\mathrm{C} 1-, \mathrm{CMB}, \mathrm{M} 1+, \mathrm{M} 1-, \mathrm{M} 2+$ and $\mathrm{M} 3+$ previously defined in the Stevns-1 borehole, Denmark (Thibault et al., 2012b) and identified in ODP Hole 762C $\delta 13 \mathrm{C}$ curve (Thibault et al., 2012a) can also be recognized in Bidart and Gubbio sections (Fig. 8). Similar durations of $\sim 800 \mathrm{kyr}$ for the M1- event are estimated at Bidart and Hole 762C (Fig. 9). Correlation of carbon-isotope stratigraphy between the two sections indicates that the studied interval covers Chron C32n.1n and about $2 / 3$ of C31r. This correlation is in 
agreement with the correlation of nannofossil bio-events (Fig. 3) between Bidart and the Gubbio sections. Differences in nannofossil biostratigraphy of these two tropical sections and southern mid-latitude ODP Hole $762 \mathrm{C}$ have been previously explained by plankton diachronism and migration patterns between the Tethyan, Transitional and Austral realms caused by palaeoceanographic reorganizations, which were triggered by the prominent climatic changes of the Campanian-Maastrichtian (Thibault et al., 2012a). According to the $\delta 13 \mathrm{C}$ correlation of Bidart to ODP Hole $762 \mathrm{C}$ and Tercis les Bains, the CampanianMaastrichtian boundary would be situated in the Bidart section at $\sim 86 \mathrm{~m}$ using Clauser's (1994) composite scale (Fig. 8C), i.e., about $7.5 \mathrm{~m}$ below the base of our studied interval.

A detailed correlation of Bidart $\delta 13 \mathrm{C}$ and magnetic susceptibility scaled records to $\delta 13 \mathrm{C}$ record and grey level variations of Gubbio sections and ODP Hole $762 \mathrm{C}$ can also be achieved as illustrated in Figure 9. This correlation indicates that the studied interval of Bidart extends from $-71.5 \mathrm{Ma}$ to $-70 \mathrm{Ma}$ (Fig. 9B and D). Correlations of the MS variations from Bidart (Fig. 9A) to the scaled grey level variations from ODP Hole 762C (Fig. 9C) indicates that the studied interval covers 13 short eccentricity cycles from cycle E10042 to E10054, with cycles on ODP Hole $762 \mathrm{C}$ being numbered downhole from the Cretaceous-Paleogene boundary (Husson et al., 2011; Thibault et al. 2012a). These results are in agreement with recent findings by Batenburg et al. (in press) obtained for the nearby Sopelana section (Spain). Recognition of the $405 \mathrm{kyr}$ cycles in the late Campanian-lower Maastrichtian of ODP Hole $762 \mathrm{C}$, and further correlation with Bidart, allows positioning of these cycles boundaries at $\sim 320, \sim 780$ and $\sim 1220 \mathrm{kyr}$ (Fig. 9A). It can be noted that the $405 \mathrm{kyr}$ eccentricity cycle maxima could be reflected by bundling of the precession cycles visible on the wavelet analysis at about 9,18 and $25 \mathrm{~m}$. The $405 \mathrm{kyr}$ eccentricity maxima in the lower Maastrichtian of Bidart thus corresponds to well defined limestone-marl couplets, which is in agreement with the modulation of the precession amplitude by the eccentricity. The increase of the magnetic susceptibility at $15 \mathrm{~m}(\sim 800 \mathrm{kyr})$ is also nearly concomitant with a minimum of the 405 kyr eccentricity (Fig. 9). This could indicate the influence of a long-term orbital control on the sedimentation that may also contribute to changes in sedimentation rate. Nevertheless, ascertaining this hypothesis would require the study of a longer record covering several 405 kyr cycles, and a detailed inventory of long term environmental changes taking place in the very active tectonic setting of the studied area. The positioning of the studied interval on the astronomical time scale of the late Campanian-Maastrichtian (Fig. 9) allows estimation of the ages of the recorded calcareous nannofossil bio-events in the Bidart section (Table 1).

\subsection{Records of palaeoenvironmental changes in the lower Maastrichtian of Bidart}

Carbon-isotopic trends at Bidart follow the global trends already highlighted and discussed in Voigt et al. (2012) and Thibault et al. (2012a, 2012b), thus allowing for precise correlation and dating of the section (Figs 8-9). Oxygen isotopes suggest a positive trend (suggesting cooling) from the base of the section to $22.5 \mathrm{~m}$, with values ranging from about $-1.8 \%$ o to -0.8 (Fig. 6). This is immediately followed by a slight shift to more negative values (suggesting warming) in the following $2 \mathrm{~m}$ and stabilization around an average of $-1.35 \%$ o to the top of the section (Fig. 6). If these trends are due to temperature changes only, and considering that bulk carbonates of the Bidart section were mainly dominated by nannofossils and nannofossil debris without any major change in dominant taxa, the long term $+0.5 \%$ o trend would suggest a decrease in sea-surface waters of about $2^{\circ} \mathrm{C}$ through the early Maastrichtian (based on the equation of Arthur et al., 1983). When replaced along the overall $\delta 180$ trend of the late Campanian-early Maastrichtian of the Bidart section previously shown by Clauser (1994), it appears that this drop in sea-surface temperatures corresponds to the progressive decreasing trend of the early Maastrichtian cooling event (Fig. 10, Barrera and Savin, 1999; Friedrich et al., 2009). This $2^{\circ} \mathrm{C}$ cooling estimate is in agreement with the previously quoted references and with surface water cooling as expressed by the greater abundance of highlatitude species in nannofossil assemblages of tropical latitude sites (Thibault and Gardin, 
2006). The comparison of $\delta 13 \mathrm{C}$ and $\delta 180$ trends in the Bidart section shows that the progressive cooling of temperatures is decoupled from the large negative CampanianMaastrichtian boundary carbon isotope excursion (CIE) (Fig. 10). This feature was already highlighted by Friedrich et al. (2009) in the Southern Ocean and South Atlantic. If $\delta 180$ values of the late Campanian are not diagenetically altered, then progressive cooling actually occurred throughout the late Campanian in the Basque-cantabric Basin and was later abruptly enhanced at around $71.9 \mathrm{Ma}$ after the major negative shift of the $\mathrm{CIE}$, giving rise to the so-called early Maastrichtian cooling event (Fig. 10).

\section{Conclusions}

Results presented in this study allow the following conclusions for the Bidart section in SW France:

- Strong orbital control of sedimentation by the precession and $100 \mathrm{kyr}$ eccentricity cycles characterizes in the lower Maastrichtian of the Bidart section. Precession cycles are particularly well-expressed in the magnetic susceptibility and oxygen isotopes and correspond well to marl-limestone couplets in the lithology.

- A relative time scale created on the basis of the identification of $100 \mathrm{kyr}$ eccentricity cycles further enhances the record of precession and $405 \mathrm{kyr}$ eccentricity cycles. Detection of these parameters thus supports a primary origin for the marl-limestone couplets, and reflects a remarkable record of precessional variations.

- Estimation of the total duration for the studied section is 1.44 +/- 0. $22 \mathrm{Myr}$.

- Correlation with the astronomically calibrated $\delta 13 \mathrm{C}$ record of ODP Hole $762 \mathrm{C}$ allows dating of the Bidart' $s \delta 13 \mathrm{C}$ record. This correlation indicates that the studied section spans the upper part of Chron C32n.1n and about 2/3 of C31r, extending from $\sim 71.5$ to $\sim 70 \mathrm{Ma}$, and covering short eccentricity cycles E10042 to E10054.

- The duration separating the LO's of U. trifidus and R. levis is evaluated to be at least $0.91+/-0.13 \mathrm{Myr}$, and is consistent with previous estimates from the Tethyan reference sections of Gubbio, Italy (Gardin et al., 2012). The LOs of A. parcus constrictus and R. levis are separated by ca. $500 \mathrm{kyr}$ in agreement with the lower Gubbio estimate of Gardin et al. (2012). Age estimates of the nannofossil biohorizons identified in the studied interval of Bidart are hereby provided (Table 1).

- Bulk oxygen isotopes suggest a $2^{\circ} \mathrm{C}$ cooling of sea-surface waters during the studied interval and corresponds to the onset and decreasing trend of the early Maastrichtian cooling event.

\section{Acknowledgments}

We thank Heather M. Stoll for providing her isotopic data of ODP Hole 762C. This study was supported by the Agence Nationale de la Recherche grant ASTS-CM.

\section{References}

Arthur, M.A., Fischer, A.G., 1977. Upper Cretaceous-Paleogene magnetic stratigraphy at Gubbio, Italy. I. Lithostratigraphy and sedimentology. Geological Society of America Bulletin 88, 367-371.

Arthur, M.A., Anderson, T. F., Kaplan, I.R., Veizer, J., Land, L.S., 1983. Stable isotopes in sedimentary geology. Society of Economic Paleontologists and Mineralogists of Tulsa Short Course no. 10 (430 pp.).

Batenburg, S.J, Gale, A.S., Sprovieri, M., Hilgen, F.J., Thibault, N., Boussaha, M., Orue-Etxebarria, X., in press. An astronomical time scale for the Maastrichtian based on the Zumaia and Sopelana sections (Basque country, northern Spain), Journal of the Geological Society, London.

Batenburg, S.J, Sprovieri, M., Gale, A.S., Hilgen, F.J., Hüsing, S., Laskar, J., Liebrand, D., Lirer, F., Orue-Etxebarria, X., Pelosi, N., Smit, J., 2012. Cyclostratigraphy and astronomical tuning of the Late Maastrichtian at Zumaia (Basque country, Northern Spain), Earth and Planetary 
Science Letters 359-360, 264-278.

Beltran, C., de Rafélis, M., Person, A., Stalport, F., Renard, M., 2009. Multiproxy approach for determination of nature and origin of carbonate micro-particles so-called "micarb" in pelagic sediments. Sedimentary Geology 213, 64-76.

Berger, A., Loutre, M.-F., 1994. Astronomical forcing through geological time. In: de Boer, P.L., Smith, D.G. (Eds.) Orbital forcing and cyclic sequences. International Association of Sedimentologists Special Publication 19, 15-24.

Böhm, F., Westphal, H., Bornholdt, S., 2003. Required but disguised : environmental signals in limestone-marl alternations. Palaeogeography, Palaeoclimatology, Palaeoecology 189, 161178.

Boulila, S., Galbrun, B., Hinnov, L.A., Collin, P-Y., 2008. High-resolution cyclostratigraphic analysis from magnetic susceptibility in a Lower Kimmeridgian (Upper Jurassic) marl-limestone succession (la Méouge, Vocontian Basin, France). Sedimentary Geology 203, 54-63.

Clauser, S., 1994. Etudes stratigraphiques du Campanien et du Maastrichtien de l'Europe occidentale (cote Basque, Charentes (France), Limbourg (Pays-Bas)). Phd Thesis, Université Pierre et Marie Curie.

Delacotte, O., 1982. Étude magnétostratigraphique et géochimique de la limite Crétacé-Tertiaire de la coupe de Bidart (Pyrénées Atlantiques). PhD Thesis, Université Pierre et Marie Curie.

Del Panta, F., 1995. Biostratigrafia e Paleoecologia a Nannofossili calcarei dellintervallo SantonianoMaastrichtiano nel dominio tetideo (Paesi Baschi, Spagna-Umbria, Italia). Correlazione con eventi a Foraminiferi. PhD Thesis, Universita degli studi di Firenze.

Dinarès-Turell, J., Baceta J.I., Pujalte V., Orue-Etxebarria X., Bernaola G., Lorito S., 2003. Untangling the Palaeocene climatic rhythm : an astronomically calibrated early Palaeocene magnetostratigraphy and biostratigraphy at Zumaia (Basque basin, northern Spain). Earth and Planetary Science Letters 216, 483-500.

Dinarès-Turell, J., Pujalte, V., Stoykova, K. and Elorza, J., 2013. Detailed correlation and astronomical forcing across the Upper Maastrichtian succession from the Basque Basin. Boletin Geologico y Minero, 124, 2, 253-282

Ellwood, B.B., Chrzanowski, T.H., Hrouda, F., Long, G.J., Buhl, M.L., 2000. Siderite formation in anoxic deep-sea sediments: A synergetic bacteria controlled process with important implications in paleomagnetism. Geology 28, 1135-1138.

Elorza, J, Garc a-Garmilla, F., 1998. Palaeoenvironmental implications and diagenesis of inoceramid shells (Bivalvia) in the mid-Maastrichtian beds of the Sopelana, Zumaya and Bidart sections (coast of the Bay of Biscay, Basque Country). Palaeogeography, Palaeoclimatology, Palaeoecology 141(1-4), 303-328.

Friedrich, O., Herrle, J.O., Wilson, P.A., Cooper, M.J., Erbacher, J., Hemleben, C., 2009. Early Maastrichtian carbon cycle perturbation and cooling event: Implications from the South Atlantic Ocean. Paleoceanography 24, PA2211.

Gallala, N., Zaghbib-Turki, D., Arenillas, I., Arz, J.A., Molina, E., 2009. Catastrophic mass extinction and assemblage evolution in planktic foraminifera across the Cretaceous/Paleogene $(\mathrm{K} / \mathrm{Pg})$ boundary at Bidart (SW France). Marine Micropaleontology 72, 196-209.

Galbrun, B., 1992. Magnetostratigraphy of Upper Cretaceous and Lower Tertiary sediments, Sites 761 and 762, Exmouth Plateau, northwest Australia. Proceedings of the Ocean Drilling Program, Scientific Results 122, 699-716.

Galbrun, B., Gardin, S., 2004. New chronostratigraphy of the Cretaceous-Paleogene boundary interval at Bidart (France). Earth and Planetary Science Letters 224, 19-32.

Gardin, S., Galbrun, B., Thibault, N., Coccioni, R., Premoli Silva, I., 2012. Bio-magnetochronology for the upper Campanian - Maastrichtian from the Gubbio area, Italy: new results from the Contessa Highway and Bottaccione sections. Newsletters on Stratigraphy 45, 75-103.

Gómez-Alday, J.J., Zuluaga, M.C.,Elorza, J., 2008. 87Sr/86Sr ratios in inoceramids (Bivalvia) and carbonate matrix as indicators of differential diagenesis during burial. Early Maastrichtian Bay of Biscay sections (Spain and France). Potential use for chemostratigraphy? Cretaceous Research, 29, 563-576.

Gorostidi, A., Lamolda, M.A., 1995. La nanoflora calcarea y el transito KT de la seccion de Bidart (SW de Francia). Revista Espanola de Paleontologia, $\mathrm{n}^{\circ}$ homenaje al Dr. Guillermo Colom, 153168.

Grossman, E.L., 2012. Oxygen isotope stratigraphy. In: Gradstein, F., et al., (Eds.). The Geologic Time Scale 2012. Elsevier, pp. 181-206.

Hinnov, L.A., 2000. New Perspectives on Orbitally Forced Stratigraphy. Annual Review of Earth and Planetary Sciences 28, 419-475. 
Hubbard, B.B., 1996. The world according to wavelets. The story of a mathematical technique in the making. Universities Press.

Husson, D., Galbrun, B., Laskar, J., Hinnov, L.A., Thibault, N., Gardin, S., Locklair, R.E., 2011. Astronomical calibration of the Maastrichtian (Late Cretaceous). Earth and Planetary Science Letters 305, 328-340.

Husson, D., Galbrun, B., Thibault, N., Gardin, S., Huret, E., Coccioni, R., 2012. Astronomical duration of polarity Chron C31r (Lower Maastrichtian): cyclostratigraphy of ODP Site 762 (Indian Ocean) and the Contessa Highway section (Gubbio, Italy). Geological Magazine 149 (2), 345351.

Locklair, R.E., Sageman, B.B., 2008. Cyclostratigraphy of the upper cretaceous Niobrara formation, western interior, USA: A Coniacian-Santonian orbital timescale. Earth and Planetary Science Letters 269, 540-553.

Lowrie, W, Alvarez, W., 1977. Upper Cretaceous-Paleocene magnetic stratigraphy at Gubbio, Italy. 3. Upper Cretaceous magnetic stratigraphy. Geological Society of America Bulletin 88, 374- 377.

Lowrie, W, Alvarez, W., 1981. 100 Million years of geomagnetic polarity history. Geology 9, 392-397.

Maurer, F., Hinnov, L.A., Schlager, W., 2004. Statistical time-series analysis and sedimentological tuning of bedding rhythms in a Triassic basinal succession (Southern Alps, Italy) In: D'Argenio, B., et al. (Eds.), Cyclostratigraphy: Approaches and Case Histories, SEPM special publication 81, 83-99.

Mayer, H., Appel, E., 1999. Milankovitch cyclicity and rock-magnetic signatures of palaeoclimatic change in the early Cretaceous Biancone formation of the southern alps, Italy. CretaceousResearch 20, 189-214.

Meyers, S.R., Sageman, B.B., 2004. Detection, quantification, and significance of hiatuses in pelagic and hemipelagic strata. Earth and Planetary Science Letters 224, 55-72.

Meyers, S.R., Sageman, B.B., Hinnov, L.A., 2001. Integrated quantitative stratigraphy of the Cenomanian-Turonian bridge creek limestone member using evolutive harmonic analysis and stratigraphic modeling. Journal of Sedimentary Research 71, 628-44.

Minoletti, F., de Rafelis, M., Renard, M., Gardin, S., Young, J., 2005. Changes in the pelagic fine fraction carbonate sedimentation during the Cretaceous-Paleocene transition: contribution of the separation technique to the study of Bidart section. Palaeogeography, Palaeoclimatology, Palaeoecology 216, 119-137.

Monechi, S., Thiersten, H.R., 1985. Late Cretaceous Eocene nannofossil and magnetostratigraphic correlations near Gubbio, Italy. Marine Micropaleontology 9, 419-440.

Mudelsee, M., 2002. TAUEST: a computer program for estimating persistence in unevenly spaced weather/climate time series. Computers \& Geosciences 28, 69-72.

Pälike, H., Hilgen, F. 2008. Rock clock synchronization. Nature Geosciences 1, 282.

Premoli Silva, I., and Sliter, W.V., 1995. Cretaceous planktonic foraminiferal stratigraphy and evolutionary trends from the Bottaccione section, Gubbio, Italy. Paleontographia Italica 82, 189.

Puigdefàbregas, C., Souquet, P., 1986. Tecto-sedimentary cycles and depositional sequences of the Mesozoic and Tertiary from the Pyrenees. Tectonophysics 129, 173-203.

Renne, P.R., Deino, A.L., Hilgen, F.J., Kuiper, K.F., Mark, D.F., Mitchell, W. S, Morgan, L.E., Mundil, R., Smit, J., 2013. Time scales of critical events around the Cretaceous-Paleogene boundary. Science 339, 684-687.

Rocchia, R., Boclet, D., Bonté, Ph., Devineau, J., Jéhanno, C., Renard, M., 1987. Comparaison des distributions de l'Iridium observées à la limite Crétacé-Tertiaire dans divers sites européens. Memoires de la Société géologique de France 150, 95-103.

Sageman, B.B., Rich, J., Arthur, M.A., Dean, W.E., Birchfield, E.G., 1997. Evidence for Milankovitch periodicities in Cenomanian-Turonian lithologic and geochemical cycles, Western Interior U.S. Journal of Sedimentary Research B67, 286-302.

Schulz, M., Mudelsee, M., 2002. REDFIT: estimating red-noise spectra directly from unevenly spaced paleoclimatic time series. Computers \& Geosciences 28, 421-426.

Seyve, C., 1984. Le passage Crétacé-Tertiaire à Pont-Labau (Pyrénées-Atlantiques, France). Bulletin du centre de recherche exploration et production Elf-Aquitaine 8, 385-423.

Stoll, H.M., Schrag, D.P., 2001. Sr/Ca variations in Cretaceous carbonates: relation to productivity and sea level changes. Palaeogeography, Palaeoclimatology, Palaeoecology 168, 311-336.

Taner, M.T., 2000. Attributes Revisited. Technical Publication, Rock Solid Images, Inc, Houston, Texas. http://www.rocksolidimages.com/pdf/attrib_revisited.htm.

ten Kate, W.G.H.Z., Sprenger, A., 1993. Orbital cyclicities above and below the Cretaceous/Paleogene boundary at Zumaya (N Spain), Agost and Relleu (SE Spain). 
Sedimentary Geolology 87, 69- 101.

Thibault, N., Gardin, S., 2006. Maastrichtian calcareous nannofossil biostratigraphy and paleoecology in the Equatorial Atlantic (Demerara Rise, ODP Leg 207 Hole 1258A). Revue de Micropaleontologie 49, 199-214.

Thibault, N., Husson, D., Harlou, R., Gardin, S., Galbrun, B., Huret, E., Minoletti, F., 2012a. Astronomical calibration of upper Campanian-Maastrichtian carbon isotope events and calcareous plankton biostratigraphy in the Indian Ocean (ODP Hole 762C): implication for the age of the Campanian-Maastrichtian boundary. Palaeogeography. Palaeoclimatology. Palaeoecology 337-338, 52-71.

Thibault, N., Harlou, R., Schovsbo, N., Schiøler, P., Minoletti, F., Galbrun, B., Lauridsen, B.W., Sheldon, E., Stemmerik, L., Surlyk, F., 2012b. Upper Campanian-Maastrichtian nannofossil biostratigraphy and high-resolution carbon-isotope stratigraphy of the Danish Basin: towards a standard $\delta 13 \mathrm{C}$ curve for the Boreal Realm. Cretaceous Research 33, 72-90.

Thomson, D.J., 1982. Spectrum estimation and harmonic analysis. IEEE Proc., 70:10551096.

Torrence, C., Compo, G.P., 1998. A practical guide to wavelet analysis. Bulletin of the American Meteorological Society 79, 61-78.

Voigt, S., Gale, A.S., Jung, C., Jenkyns, H.C., 2012. Global correlation of Upper Campanian Maastrichtian successions using carbon-isotope stratigraphy: development of a new Maastrichtian timescale. Newsletters on Stratigraphy 45, 25-53.

Westerhold, T., Röhl, U., McCarren, H.K., Zachos, J.C., 2009. Latest on the absolute age of the Paleocene-Eocene thermal maximum (PETM) : New insights from exact stratigraphic position of key ash layers +19 and -17 . Earth and Planetary Science Letters 287, 412-419.

Westphal, H., Hilgen, F., Munnecke, A., 2010. An assessment of the suitability of individual rhythmic carbonate successions for astrochronological application. Earth-Science Reviews 99, 19-30. Wilks, D.S., 1995. Statistical Methods in the Atmospheric Sciences. Academic Press, San Diego (467pp.).

Zepeda, M.A., 1998. Planktonic foraminiferal diversity, equitability and biostratigraphy of the uppermost Campanian-Maastrichtian, ODP Leg 122, Hole 762C, Exmouth Plateau, NW Australia, eastern Indian Ocean. Cretaceous Research 19, 117-152. 